\title{
Resolusi Maqasid Al-Syariah Terhadap Penanggulangan Virus Covid-19
}

\author{
Sudirman \\ Muhammad Rusdi Rasyid \\ Institut Agama Islam Negeri Sorong \\ sudirmaniainsorong@gmail.com \\ rusdipasca@gmail.com
}

\begin{abstract}
Abstrak: This research try to examine the resolution of maqasid sharia against the Covid-19. This study uses a qualitative approach and make maqasid sharia as grand theory for analyzing the prevention of the Covid-19. The phenomenon in society who think that the Corona virus causes many effect in religious ritual, such as stopped a while for Friday prayers, recitation, silaturrahim, burial education and others. The results show that the view of maqasid sharia on the prevention of the Corona virus saw aspects of benefit. Leaving something maslahat that can lead to mafsadat is a requirement in maqasid sharia. So maqasid sharia makes religion easy to practice without endangering the five principles of human priority, likes; maintain religion, spirit, intellect, life, and property.
\end{abstract}

Keyword: Resolution, Maqasid sharia, Covid-19.

Abstrak : Fokus penelitian ini mengkaji resolusi maqasid syariah terhadap penanggulangan virus Covid-19. Penelitian ini menggunakan metodependekatan diskriktif kualitatif menjadikan teori maqasid syariah sebagai grand teori untuk menganalisis penganggulangan virus Covid-19. Fenomena pada masyarakat yang berpandangan bahwa virus Corona membuat anjuran agama ditinggaalkan, seperti halnya salat jumat, pengajian, silaturrahim, pendidikan diluburkan dan lain-lainnya. Hasil penelitian menunjukkan bahwa pandangan maqasid syariah terhadap penanggulangan virus Corona melihat aspek kemaslahatan. Meninggalkan sesuatu yang maslahat yang dapat menimbulkan mafsadat adalah tuntutan dalam teori maqasid syariah. Sehingga teori mawasid syariah memberikan kemudahan dalam menjalankan agama dengan tidak membahayakan lima prinsip prioritas manusia, yaitu; menjaga agama, jiwa 
keturunan, akal, dan harta. Jika keli hal ini terjaga dengan baik maka manusia akan bahagia dunia dan akhirat.

Kata Kunci: Resolusi, Maqasid al-syariah, Virus Covid-19.

\section{Pendahuluan}

Dunia digegerkan dan dilumpuhkan oleh penyebaran virus covid-19. Asal mula virus ini berkembang di kota Wuhan Cina pada awal akhir tahun 2019. Penyebarannya begitu cepat sehigga menular kebeberapa Negara lainnya seperti Italia, Iran, Korea, termasuk Indonesia.

Jumlahnya yang semakin hari semakin bertambah begitu juga penyebarannya yang semakin meluas menjadikan ancaman bagi kehidupan manusia. Akibatnya perekonomian mulai merosot dan melemah bagi Negara yang terkena dampak serta masyarakatnya mulai merasa terancam.

Berbagai kebijakan dikeluarkan termasuk social distancing/ phisycal distancing atau menjaga jarak antara manusia dengan manusia lainnya, diharuskannya ada jarak minimal agar potensi penularannya menurun. Bahkan dibeberapa Negara seperti Cina, Italia, India, Polandia, Irlandia, Spanyol, Denmark serta Negara-negara lainnya yang tergolong terkena dampak Virus ini melakukan hal yang sama yaitu menghentikan seluruh aktivitas dengan berdiam diri di kediaman masing-masing. ${ }^{1}$

Kegaitan yang sifatnya perkumpulan-perkumpulan dilarang, baik aktifitas perekonomian seperti kegiatan pada pusat-pusat pembelanjaan serta pasar-pasar. Bahkan kegiatan ritual keagamaan juga telah mendapat himbauan untuk tidak dilakukan secara berjamaah atau berkelompok. Seperti kegiatan salat jamaah, salat jumat, umrah, perkawinan, kegiatan gereja, kegiatan nyepi dan banyak lagi kegiatan manusia lainnya yang selama ini dilakukan secara bersama-sama dengan virus corona semua telah dilarang.

Pelarangan-pelarangan tersebut merupakan langkah preventif agar penyebaran virus Corona dapat teratasi sehingga penanguulangannyapun

${ }^{1}$ https://news.detik.com/berita/d-4956298/daftar-negara-yang-lockdownkarena-corona/5 
mudah diantisipasi. Langkah preventif ini akan berdampak pada berhentinya atau hilangnya virus Corona tersebut.

Di Indonesia sendiri telah banyak himbauan serta adaran yang mengharuskan masyarakat untuk tidak beraktifitas di luar rumah serta mengurangi kegiatan yang sifatnya mengumpulkan banyak orang. Namun tidak semua masyarakat mengindahkan himbauan yang dikeluarkan pemerintah pusat ataupun pemerintah daerah, ataukah himbauan yang dikeluarkan oleh majelis ulama ataukah Persekutuan Gereja-Gereja Indonesia yang mengharuskan ibadah dirumah masing-masing.

Lebih khusus lagi terhadap perilaku masyarakat yang beragama Islam, banyak masyarakat yang justeru melakukan salat jumat secara berjamaah, salat lima waktu berjamaah dimasji-masjid, hajatan, resepsi perkawinan serta banyak lagi kegiatan lainnya yang mengakibatkan terjadinya suatu kerumunan masyarakat padahal telah ada larangan untuk melakukan hal-hal di atas selama masih mewabahnya penularan vicrus corona.

Persepi yang bermunculan berbeda-beda, ada yang berprinsip bahwa kalau mati sudah ada ketentuannya sehingga salat jamaah merupakan hal yang harus dilakukan apapun konsekuensinya. ${ }^{2}$ Ada juga yang berpendapat bahwa belum masuk dalam zona merah atau tempat yang dia tinggali belum ada yang positif Corona sehingga masih bisa dilakukan salat secara berjamaah, serta ada juga yang berperinsip bahwa memang harus ditinggalkan agar tidak terjangkit virus tersebut.

Berdasarkan fenomena masyarakat tersebut sehingga perlu adanya kajian yang memberikan dasar kuat mengapa kegaiatan ritual keagamaan selama ini yang sifatnya wajib justeru telah terbalik menjadi makruh bahkan haram untuk dilakukan seperti salat jumat, salat berjamaah, melakukan resepsi, menjaling siturrahim yang kesemuanya saat virus corona masih mewabah sangat dilarang.

Dalam literature kajian Islam terdapat kajian tentang maqasidu alsyariah sekaligus dijadikan pisau analisis dalam kajian tulisan ini, yang membahas tentang resolusi maqaidu al- syariah dalam penanggulangan penyebaran virus Corona. Penelitian ini bertujuan untuk menegaskan 
bahwa ada kalanya suatu hukum dapat berubah sesuai dengan situasi dan kondisi tempat dan waktunya. Sekaligus peneltian ini akan menjawab fenomena persepsi masyarakat yang tidak mengindahkan larangan pemerintah untuk tidak berkerumun yang berdalih sedang menjalankan perintah agama untuk salat berjaah serta ritual lainnya.

\section{Tinjauan Pustaka}

Pertama: oleh Musolli pada sebuah jurnal At-Turas: jurnal studi keislaman, yang berjudul maqashid Syariah: kajian teoritis dan aplikatif pada isu-isu kontemporer pada tahun 2018. Pada tulisan ini memuat tentang bahwa maqashid Syariah merupakan pintu gerbang yang menandakan an-najah jaran Islam mampu mengimplementasikan ajarannya Relevan dengan setiap permasalahan yang timbul sehingga lahir sebuah solusi terhadap masalah-masalah apapun yang dihadapi oleh manusia. ${ }^{3}$ Adapun persamaan dengan kajian tulisan ini adalah ah teu letak pada ada pisau analisis yaitu maqashid Syariah namun khusus pada tulisan ini akan membahas tentang yang ceria dalam memberikan resolusi terhadap fenomena penyebaran wabah virus Corona.

Kedua: oleh Ridwan Jamal Pada sebuah jurnal ilmiah al-Syirah, yang berjudul maqosid Syariah dan relevansinya dalam konteks kekinian pada tahun 2016. pada jurnal ini Lebih banyak memuat tentang yang penjelasan tentang kebutuhan manusia yang harus dimiliki oleh manusia itu sendiri seperti pemenuhan kebutuhan primer, sekunder, dan tersier. begitu pulang menegaskan bahwa memahami dinamika hukum Islam berat hubungannya dengan maqashid syariah yang berorientasi kepada kemaslahatan dunia dan akhirat sehingga pemahaman terhadap maqashid Syariah Dapat mengembangkan ijtihad dalam menjawab permasalahan hukum kontemporer. ${ }^{4}$ Adapun perbedaan dengan penelitian ini, meskipun pada konteksnya menjadikan maqashid Syariah sebagai pisau analisis namun pada penelitian ini lebih berfokus kepada bagaimana

${ }^{3}$ Musolli Musolli, "Maqasid Syariah: Kajian Teoritis Dan Aplikatif Pada IsuIsu Kontemporer,” AT-TURAS: Jurnal Studi Keislaman 5, no. 1 (2018): 60-81, https:// doi.org/10.33650/at-turas.v5i1.324.

${ }^{4}$ Ridwan Jamal, "Maqashid Al-Syari'Ah Dan Relevansinya Dalam Konteks Kekinian,” Jurnal Ilmiah Al-Syir'ah 8, no. 1 (2016): 1-12, https://doi.org/10.30984/ 
maqashid Syariah menjadi sebuah resolusi untuk menjawab app fenomena terhadap masyarakat akan Multi persepsi terhadap himbauan dalam pencegahan penyebaran virus Corona.

Ketiga: oleh Nurdhin Baroroh Sebuah jurnal Al Mazahib, yang berjudul metamorfosis illat hukum dalam sad adz-dzari'ah dan fath adz-dzari'ah (sebuah kajian perbandingan) pada tahun 2017. Dalam penjelasan jurnal ini memuat tentang bahwa sad adz-dzari'ah adalah suatu metode yang dihasilkan oleh ulama Ushul fiqih terdahulu untuk menjaga manusia terjadi kepada kerusakan atau kemafsadatan dengan menutup semua sarana untuk suatu perbuatan Cara menyembuhkan jalan keluar dari suatu permasalahan sehingga baik dari ad adz-dzari'ah dan fath adz-dzari' ah adalah merupakan metode ijtihad untuk menemukan solusi. ${ }^{5}$ Adapun persamaan dalam kajian penelitian ini terdapat pada adanya suatu metode untuk mengarah kepada maqashid syariah atau maksud dari Allah menetapkan hukum-hukumnya kepada manusia termasuk yang di antaranya adalah metode ad adz-dzari'ah dan fath adz-dzari' ah. metode ini akan digunakan untuk melihat fenomena pandemi virus Corona yang mana adanya larangan untuk melakukan hal-hal yang selama ini menjadi kewajiban seperti salat berjamaah serta ibadah lainnya, akibat adanya virus korona ini sehingga hal tersebut justru Terlarang. Kajian dzad adz-dzari'ah dan fath adz-dzari'ah merupakan salah satu metode ijtihad untuk menemukan solusi tersebut.

\section{Metode Penelitian Pembahasan}

Pendekatan penelitian yang digunakan adalah deskriptif kualitalif, untuk memahami fenomena tentang apa yang dialami oleh subjek penelitian pada suatu konteks khusus yang alamiah ${ }^{6}$. Penelitian kualitatif deskriptif bertujuan untuk; (1) untuk menggambarkan kegiatan penelitian yang dilakukan pada objek tertentu secara jelas dan sistematis; (2) melakukan eksplorasi dengan tujuan untuk dapat menerangkan dan

as.v8i1.34.

5 Nurdhin Baroroh, "Metamorfosis Illat Hukum Dalam Sad Adz-Dzari'ah Dan Fath Adz-Dzari'ah,” Al-Mazahib 5, no. 2 (2017): 289-304.

${ }^{6}$ Lexy J. Moleong, Metodologi Penelitian Kualitatif, ed. XXXI (Bandung: PT. Remaja Rosdakarya, 2013). 
memprediksi terhadap suatu gejala yang berlaku atas dasar data yang diperoleh di lapangan ${ }^{7}$. Penelitian mengkaji resolusi maqasid syariah terhadap virus Covid-19. Teori ini dianggap relevan dalam menganalisis fenomena masyarakat yang setelah ada larangan untuk berkumpul baik dalam praktik social maupun ibadah.

Metode penelitian dalam penelitian ini adalah studi kasus (case studi). Peneliti mengamati secara mendalam terhadap program, kejadian, proses, aktivitas dan terhadap satu orang atau lebih. Suatu kasus terikat oleh waktu dan aktivitas, sehingga peneliti melakukan pengumpulan data secara mendetail dengan menggunakan berbagai prosedur pengumpulan data dan dalam waktu yang berkesinambungan ${ }^{8}$.

\section{Kajian Maqasid AI-Syariah}

Peristilahan kata ijtihad merupakan perbincangan yang sangat lazim dalam pengembangan hukum khususnya dalam literature ushul fikhi, hal ini memberikan dampak terhadap jawaban-jawan terkait permasalahan sosial yang berada di tengah-tengah masyarakat. ${ }^{9}$ Solusi yang jitu terhadap permasalahan tersebut akan terurai dalam hasil ijtihad yang mnggunakan seluruh kemapuan para ijthad dalam menggali hukum dari sumbernya.

Hasil ijtihad diharapkan dalam membendung perubahan sosial serta mempengeruhi perubahan-perubahan social. Mengarahkan perubahaan sosial kepada tujuan hukum dan menjadikan perubahan hokum sebagai perekayasa social (social Engenering). Hal ini seiring dengan pandangan sosiologi hukum bahwa hokum dijadikan sebagai alat control social terhadap perubahan yang terjadi dalam prilaku manusia dan hokum dapat dijadikan sebagai perekayasa sosia. ${ }^{10}$

${ }^{7}$ Sukardi, Metodologi Penelitian Pendidikan Kompetensi Dan Praktiknya, Cet: II (Jakarta: PT. Bumi Aksara, 2004).

${ }^{8}$ Sugiyono, Metode Penelitian Kombinasi, Cet: II (Bandung: Alfabeta, 2012).

9 Transformasi Hukum et al., "Guru Besar Dalam Bidang Ilmu Pemikiran Hukum Islam Pada Fakultas Syariah Dan Hukum UIN Alauddin Makassar. Jurnal Al-Qadāu Volume 2 Nomor 1/2015 | *” 2 (2015): 1-14.

${ }^{10}$ Soerjono Soekanto, Pokok-Pokok Sosiologi Hukum ( Jakarta: Rajawali Pres, 1980), h. 115 
Sehingga ijtihad memegang dua peanan secara bersamaan yaitu merubah dan mengarahkan manusia kejalan bermaslahat. Menurut alTiwana fungsi ijtihat terbagi 3 yaitu: Pertama; ijtihad sebagai penjelas dan peneafsiran terhadap teks nash. Dua; ijtihad terhadap metode qiyas dalam menggali hokum-hukum yang telah ada dan disepakati. Tiga; Ijtihad dalam penggunaan metode $r a^{\prime} y u .^{11}$

Salah satu konsep terpenting hasil ijtihad dalam literature Islam adalah fundamentalis pembahasan maqasid al-syari'ah. Konsep ini sekanakan hadir mengaskan urgensinya dalam mewujudkan kemaslahatan kehidupan manusia. Para ulama pun tidak mengingkari bahkan justru menjadikan sebagai pokok bahasan dan kajian semasa hidupnya. Jika mengkaji dari seluruh litertur maqasid syariah maka poin paing penting yang harus dipahami adalah mewujudkan suati nilai yang baik sekaligus menghindarkan keburukan atau mengembil manfaat dan menolak mafsadat (dar'u al-mafasid wa jalb al mashalih).

Dari segi pengertiannya terdapat dua kosa kata yaitu al-maqasid yang sering diartikan sebagai tujuan dan syariah adalah sumber mata air. Kedua kata ini dalam kajian berbagai literature memberikan pandangan bahwa jika disimpulkan kedua maksud kata ini akan bermuara pada tujuan utama Allah memberikan syara' kepada manusia.

Pengertian ini seiring dengan pengertian Ibn Ashur yang memberikan definisi terhadap maqasid syariah yakni nilai aau hikmah yang enjadi objek seluruh kandungan syariat baik sifatnya khusus maupun umum. Yang didalanya memuat nilai seperti mederasi, toleran dan holistic. ${ }^{12}$

Secara umumnya para ulama memberikan gambaran bahwa kajian terhadap maqasid syariah hanya berpusat pada lima pokok kemaslahatan yaikni: Kemaslahatan agama; kemaslahatan jiwa; kemaslahatan akal; kemaslahatan keturunan dan kemaslahatan harta. Sedangkan dari eksistensi tingkatannya mencakup tingkatan dharuriyyah (prioritas atau

\footnotetext{
${ }^{11}$ Muhammad Musa al-Tiwana, Ijtihad wa Mada Hajatina Ilaih fi Hadza al- A Asr (T,t, Dar Kutub al-Hadisah, t.th), h 39

${ }^{12}$ Abd Al-Rahman Ibrahim al-Kailani, Qawaid al-Maqasid inda al-Imam alsyatibi: 'Ardan wa Dirasatan wa Tahlilan (Damishq: Dar al-Fikr, 2000), 46
} 
primer), Hajjiyyat ( Sekunder) dan tahsiniyyat (tersier/pelengkap). ${ }^{13}$ Sedangkan Menurut al Ghazali bahwa yang termasuk dalam aspek dhruriyyat dalam hal ini adalah menjaga kelima hal poko tersebut yaknia menjaga agama, jiwa, akal, harta dan keturunan. ${ }^{14}$

Dalam konsep maqasid al-syariah al-Syatib memakai konsep maslahat sebagai tujuan tuhan menciptakan syariat (qashd al-syari'). Kemaslahatan metupakan hal yang mutlak harus ada dalam suatu syariat karena merupakan tolok ukur dalam mencapai kebahagiaan dunia dan akhirat manusia. Sehingga orientasi maslahat harus mencakup keduanya dan tidak boleh melalaikan salah satunya. Bukanlah dikatakan sebagaimaslahat jika hanya maslahat di dunia saja begitu juga sebaliknya. ${ }^{15}$

Maslahat yang terbentuk dari akal pemikiran manusia tentunya tidak bisa tercapai jika tampa kolaborasi tuntunan syariat yang tertuang dalam nash. Jika melihat pemikiran al-Syatibi maka kemaslahatan yang diwujudkan manusia adalah kemaslahatan kepentingan manusia, namun tidak boleh mengikutii dorongan nafsu manusia agar apapun yang dinilainya maslahat maka akan dia lakukan namun harus tetap berdasar pada syariat tuhan. Karea eksistensi syariat bagi manusia adalah pedoman kemaslahatan itu sendiri.

Al-Syatibi dalam mengali maslahat membagi kepada tiga macam kemaslahatan:

\section{Daruriyyat}

Dalam skala prioritas ini, segala sesuatu yang merupakan kebutuhan pokok manusai yang dapat menjamin kemaslahatan kehidupan manusia dusian dan akhirat. Ada lima hal menjadi skala prioritas dalam pekirannya yaitu; memelihara agama, jiwa, akal, keturunan dan harta. ${ }^{16}$

${ }^{13}$ Al-Syatibi, Al-Muwafaqat fi Ushul al-Syariah ( Kairi: Mustafa Muahammad, t,th) h. 8

${ }^{14}$ Al-Ghazali, al-Mustasfa min 'Ilm al-Ushul, Jilid I (Kairo: al- Amiriyyah, 1412), h. 250

${ }^{15}$ Al-Syatibi, Al-Muwafaqat fi Ushul al-Syariah ( Kairi: Mustafa Muahammad, t,th) h. 37 dan 127 t,th) h. 127

${ }^{16}$ Al-Syatibi, Al-Muwafaqat fi Ushul al-Syariah ( Kairi: Mustafa Muahammad, 
Menjaga agama denagan cara menjalankan perintah agama dan menjauhi segala larangannya seperti salat, puasa, zakat haji, berperang, menyebarkan kebaikan agama serta lainnya. Menjaga jiwa dengan menjauhi segala hal yang dapat membinasakan jiwa manusia. Menjaga keturunan membuka pintu pernikahan untuk memperoleh keturunan dengan cara yang sah danpelarangan bagi penuduh berbuat zina serta hukumnannya. Menjaga harta dengan adanya hukuman bagi penjudi, pencuri, perampok, penipu serta hal yang buruk lainnya berkaitan dengan perolehan harta, sebaliknya anjuran untuk mengembangkan dan memperoleh harta dengan cara yang baik. ${ }^{17}$ Menjaga akal dengan menuntut ilmu penegtahuan agar dapat produktif serta mengetahui eksistensi kehidupan sebaliknya agar tidak sesat dan disesatkan pengetahuan yang mengarah kesesatan. Kesemua hal ini merupakan konsep yang sangat prioritas dalam kehidupan manusia untuk mencapai kemaslahatan.

\section{Hajjiyat}

Pemenuhan kebutuhan maslahat sekunder ini sangat penting meskipun tidak mengancam langsung merusak kemaslahatan umum dalam konsepa daruriyyat, namun akan berdampak pada timbulnya suatu kesulitan. Sehingga konsep utama yag ditawarkan dalam maslahat hajjiyat ini adalah menghilangkan kesilitan, meringankan beban tanggung jawab manusia dan memudahkan urusan manusia baik dalam aspek ibadah, muamalat maupun dalam perkara pidana. ${ }^{18}$ Sebagai contoh dalam kasusini, seperti kejadian saat pandemic virus Corona yang menggugurkan kewajiban salat jumat dengan menggantikan dengan salat duhur dirumah.

${ }^{17}$ Farida Farida and Veni Soraya Dewi, “Analisis Pengaruh Penerapan Kinerja Maqasid Terhadap Manajemen Risiko Pada Perbankan Syariah," Cakrawala: Jurnal Studi Islam 12, no. 2 (2017): 171-86, https://doi.org/10.31603/cakrawala.v12i2.1858.

${ }^{18}$ Nabila Zatadini and Syamsuri Syamsuri, “Konsep Maqashid Syariah Menurut Al-Syatibi Dan Kontribusinya Dalam Kebijakan Fiskal," AL-FALAH : Journal of Islamic Economics 3, no. 2 (2018): 1, https://doi.org/10.29240/alfalah.v3i2.587. 


\section{Tahsiniyyat}

Pada aspek tersier ini hanya sekedar sebagai pelengkap atau bumbu $\mathrm{y}=$ unuk memperindah sesuatu hal. Meskipun dalam suatu hal maslahat ini tidak ada maka tidak akan mengganggu eksistensi maslahat dharuruyyat dan hajjiyat. Akan tetapi jika maslahat tahsiniyyat ini tidak terwujud maka menimbulkan kondisi yang kurang harmonis dalam penilaian akal sehat. ${ }^{19}$ Karena maslahat ini lahir dari akal sehat dan kebiasaan yang bermuara pada etika hidup yang baik.

Ketiga maslahat ini merupakan suatu kesatuan yang kolektif dan tidak dapat dipisahkan satu dengan yang lainnya. meskipun ada tingkatan skala prioritasnya namun bukanlah merupakan harus berpedoman kepada daruriyyat semata sehingga mengabaikan maslahat lainnya. karena kebutuhan manusia merupakan ketiga hal tersebut demi terwujudnya kemaslahatan.

\section{Resolusi Maqasid Syariah Terhadap Penanggulangan Pandemi Virus Covid-19}

Penjelasan singkat mengenai maqasid syariah di atas yang memberikan gambaran bahwa ada lima hal pokok yang merupakan skala prioritas dalam kehidupan manusia yaitu menjaga eksistensi agama, jiwa, akal, harta dan keturunan ${ }^{20}$. Sedangkan untuk penyempurnaan atau pendukung pemenuhan tersebut masuk kepada dukungan hajjiyyat dan tahsiniyyat. Terkait dengan Penanggulangan virus Corona maka konsep maqasid syariah meninjau hal tersebut baik dari segi eksistensi maupun tingkatannya, sebagai berikut:

Hak beragama yaitu hak yang melekat untuk beribadah dan menjalankan perintah agama serta menegakkan ajaran-ajarannya. Hak ini tidak hanya berpandangan bahwa hak agama hanya sekedar

${ }^{19}$ Kholid Hidayatullah, "Mazhab Ulama Dalam Memahami Maqashid Syari'ah," Ulul Albab: Jurnal Studi Dan Penelitian Hukum Islam 1, no. 1 (2017): 1, https://doi.org/10.30659/jua.v1i1.1971.

${ }^{20}$ Indra, "Maqashid Syariah Menurut Muhammad Thahir Bin Asyur," 2016, 112, https://drive.wps.com/d/ANxjamCko-gboMioxIydFA\%0A[Berkas]Maqashid Syariah menurut Muhammad Thahir bin Asyur.pdf. 
menjalanakan perintah agama namun cakupannya luas, diantaranya membangun sarana peribadatan dan membengun relasi yang kuat dalam menengakkan agama baik seakidah maupun terhadap agama lainnya.

Menegakkan agama merupakan perintah yang konkrit dari ajaran agama baik sifatnya mahdah amupu gairu mahdah, agar tujuannya tercapai yakni menjalankan perintah dan mengharap ridha Allah. Namun tidak semua perintah dalam situasi tertentu dapat dijalankan secara normal. Ada waktu-waktu tertentu sehingga berpaling dari hokum yang satu kehukum yang lainnya. Seperti halnya virus corona yang mewabah mengharuskan beberapa peribadatan harus ditinggalkan.

Terlebih dahulu dipaparkan beberapa ayat dalam al-Qur'an menjelaskan terkait dengan musibah atau peristiwa termasuk tentang kejadian dalam suatu penyakit. Meskipun penamaan penyakit yang dimaksud tidak langsung menyebut nama penyakitnya. Melaingkan hanya menyinggung secara umum untuk kejadiannya. Seperti dalam QS. Al-Hadid/57:22-23:

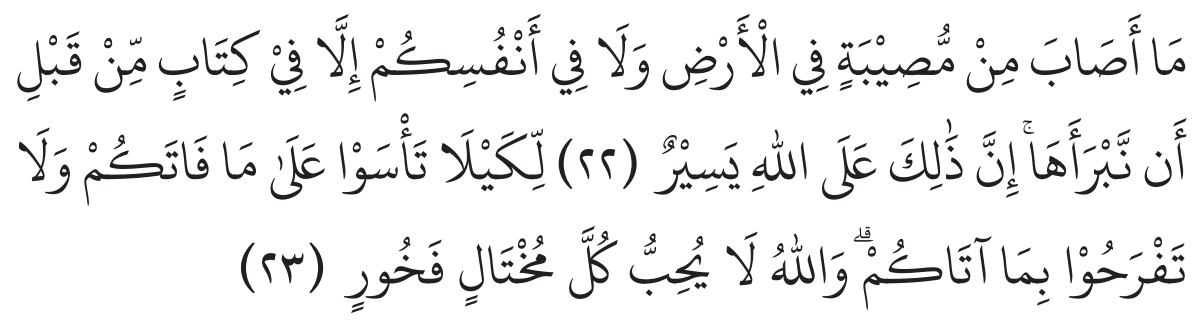

Terjemahnya:

Setiap bencana yang menimpa di bumi dan yang menimpa dirimu sendiri, semuanya telah tertulis dalam Kitab (Lauh Mahfuzh) sebelum Kami mewujudkannya. Sungguh, yang demikian itu mudah bagi Allah. Agar kamu tidak bersedih hati terhadap apa yang luput dari kamu, dan jangan pula terlalu gembira terhadap apa yang diberikan-Nya kepadamu. Dan Allah tidak menyukai setiap orang yang sombong dan membanggakan diri. (QS. alHadid [57]: 22-23)

Maksud dalam ayat ini, menurut tafsir al-Mukhtashar/Markaz Tafsir Riyadh dibawah bimbungan Syaikh Shalih bin Abdullah bin Humid Imm besar masjid Haram bahwa bahwa manusia ditimpah 
musibah di dunia ini berupa penyakit, kelaparan, dan rasa sakit, kecuali tertulis di lauhil mahfud sebelum makhluk diciptakan. ${ }^{21}$

Dalam ayat ini memberikan penjelasan bahwa Allah menciptakan segala sesuatunya termasuk dalam hal musibah seperti Covid-19. Sehingga apapun bentuk musibah dan penyakit yang dirasakan oleh umat manusia merupakan suatu ketetapan dan sebagai cobaan. Namun yang harus disikapi oleh umat manusia adalah bagaimana memberikan perhatian terhadap cobaan yang diberikan tersebut berdasarkan ayat al-Qur'an.

Cobaan atau dampak virus tersebut justeru memberikan pengaruh yang besar dalam menjalankan perintah agama yang selama ini dilakukan dan setelah adanya virus tersebut justru dilarang. Seperti umrah, salat berjamaah, salat jumat berjamaah, melakukan pengajian, sekolah, mencari nafkah anak istri dalam bekerja. Kesemua hal ini telah dilarang dengan munculnya regulasi dan edaran sebagai langkah antisipatif dalam mencegah penyebaran lebih meluas terhadap virus Corona tersebut.

Dalam kajian maqasid syariah maka jelas menjalankan menjaga eksistensi agama merupakan hal yang pokok. Akan tetapi hal ini tidak boleh dijadikan sebagai dasar utama sehingga mengancam eksistensi hal darurat lainnya seperti terancamnya jiwa. Karena jika suatu peristiwa atau keadaan mengancam salah satu dari kelima hal tersebut maka hokum asal dapat dikesampingkan dengan mencari hokum kemaslahatan lainnya.

Pengambilan keputusan hukum ini juga merupakan ajaran agama serta menjaga eksistensi agama. Karena pada konsepnya hal ini bukan merusak eksistensi agama, melainkan menajalankan konsep agama yang lainnya sehingga eksistensi agama justru terjaga dengan baik. Sehingga yang harus dilakukan adalah berdiam diri sesuai dengan ajara agama.

Dalam kajian kaidah ushul fikhi menyebutkan bahwa "Kesulitan menyebabkan adanya kemudahan" sehingga kesulitan yang dialami umat manusia dalam menjalankan perintah ibadah semisal salat jumat, maka hukum salat jumat berjamaah bagi laki-laki yang dulunya wajib digantidkan dengansalat zuhur dirumah. Hal ini sesuai dengan hadis

${ }^{21} \mathrm{https} / /$ tafsirweb.com/10718-quran-surat-al-hadid-ayat-22.html 
"Barang siapa yang mendengar azan wajib baginya sholat berjamaah di masjid, kecuali ada uzur". Para sahabat bertanya : "Apa maksud uzur ?". Jawab Rasulullah SAW: "Ketakutan atau sakit." (HR. Abu Daud)

Dalam kaidah ushul fikhi ditegaskan bahwa "Menolak mafsadah didahulukan dari pada mecari kemaslahatan". Sikap lockdown yang dilakukan selain menjalankan dari amanat pemerintah juga telah secara otomatis menjalankan syariat agama. Sehingga posisi ini seharusnya memberikan kepatutan yang berlebih yaitu taat terhadap anjuran agama dan patut kepada himbauan pemerintah. Hal ini dilakukan oleh nabi saat wabah Tha'un melanda, wabah tersebut dapat di qiyaskan kepada wabah Covid-19 yang mengharuskan setip orang untuk mengisolasi diri di kediaman masing-masing.

Jika menelusuri dari histori pencegahan terdahulu, sejak nabi Muhammad saw. telah memberikan contoh dalam menyikapi suatu situasi wabah. Seperti dalam sebuah hadis.

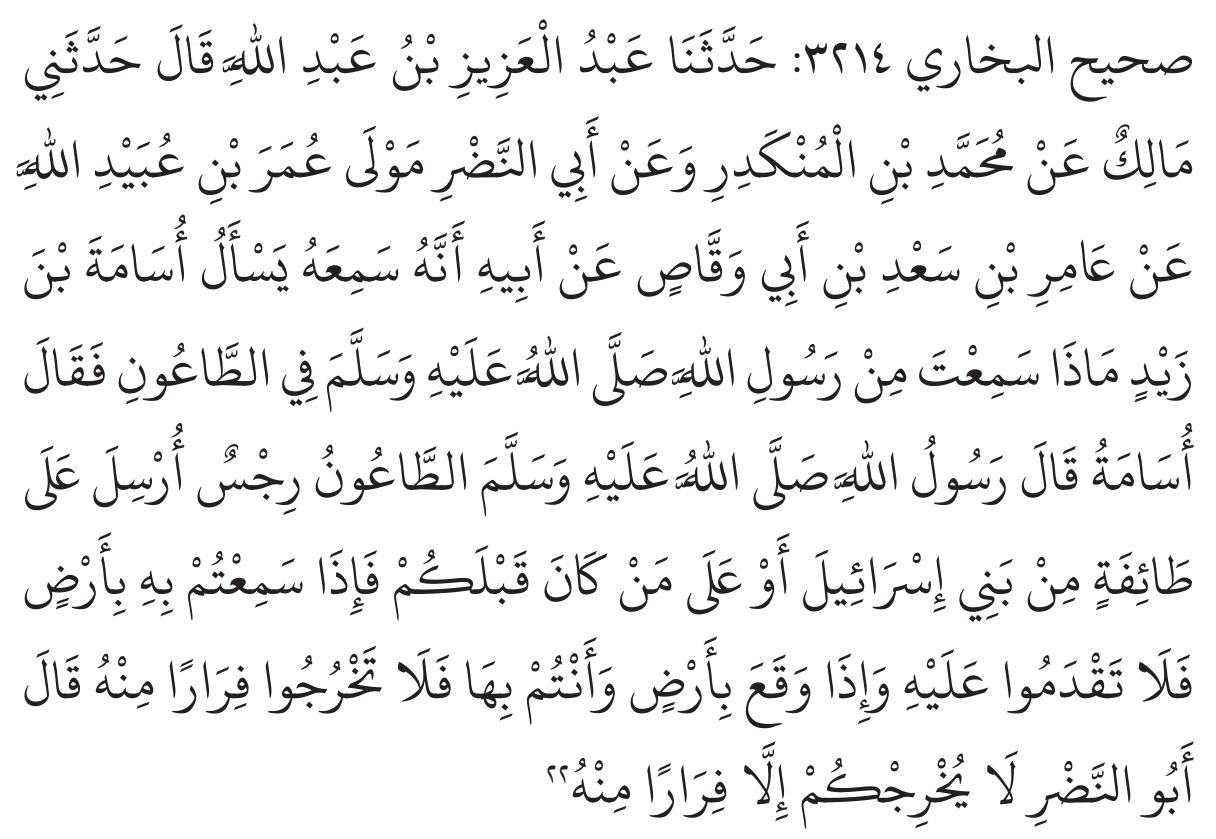

Shahih Bukhari 3214: Telah bercerita kepada kami 'Abdul 'Aziz bin 'Abdullah berkata: telah bercerita kepadaku Malik dari

${ }^{22}$ Aplikasi HadisSoft versi 4.0.0 
Muhammad bin Al Munkadir dan dari Abu An-Nadlar, maula 'Umar bin 'Ubaidullah dari 'Amir bin Sa'ad bin Abu Waqash dari bapaknya bahwa Dia ('Amir) mendengar bapaknya bertanya kepada Usamah bin Zaid: "Apa yang pernah kamu dengar dari Rasulullah shallallahu 'alaihi wa sallam tentang masalah tha'un (wabah penyakit sampar, pes, lepra)?" Maka Usamah berkata: Rasulullah shallallahu 'alaihi wa sallam bersabda: "Tha'un adalah sejenis kotoran (siksa) yang dikirim kepada satu golongan dari Bani Isra'il atau kepada umat sebelum kalian. Maka itu jika kalian mendengar ada wabah tersebut di suatu wilayah janganlah kalian memasuki wilayah tersebut dan jika kalian sedang berada di wilayah yang terkena wabah tersebut janganlah kalian mengungsi darinya." Abu An-Nadlar berkata: "Janganlah kalian mengungsi darinya kecuali untuk menyelematkan diri."

Hadis ini menunjukkan bahwa antispatif yang dilakukan saat ini adalah sesuai maksud amalan Nabi saat menangani penyebaran wabah. Lebih lanjut dalam satu hadis menunjukkan bahwa:

Rasulullah saw bersabda: "Wabah Tha'un adalah suatu ayat, tanda kekuasaan Allah Azza Wajall yang sangat menyakitkan, yang ditimpakan kepada orang-orang dari hambaNya. Jika kalian mendengar berita dengan adanya wabah Tha'un, maka jangan sekali-kali memasuki daerahnya, jika Tha'un telah terjadi pada suatu daerah dan kalian disana, maka janganlah kalian keluar darinya." (HR. Muslim) .

Hal serupa yang dilakukan oleh Umar yang dalam suatu riwayat dijelaskan:

Instruksi dalam hadis tersebut sangatlah jelas bahwa menghindari suatu keadaan yang buruk merupakan hal yang di syariatkan dalam Islam. bukan berarti menggantungkan nasib pada taktir, sehingga jika terjadi wabah di suatu tempat dan tetap ingin masuk dalam lingkungan wabah maka sama halnya ingin menempatkan diri dalam kebinasaan. Sedangkan jelas dalam ayat QS. Al-Baqarah/2:195. 


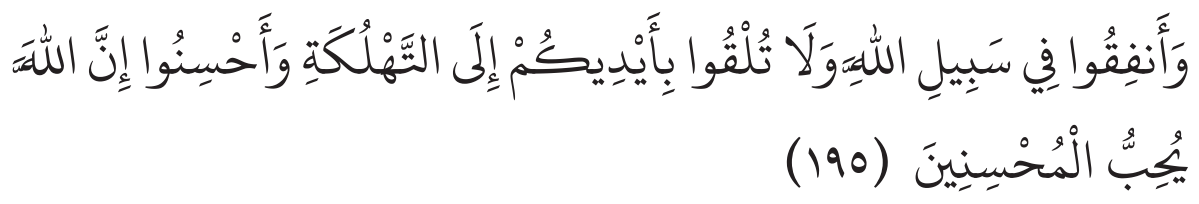

Terjemahnya:

Dan belanjakanlah (harta bendamu) di jalan Allah, dan janganlah kamu menjatuhkan dirimu sendiri ke dalam kebinasaan, dan berbuat baiklah, karena sesungguhnya Allah menyukai orangorang yang berbuat baik.

Setiap manusia harus memprioritaskan kesalamat jiwanya agar kemaslahatan dapat terwujud dalam kehidupannya. Agama jelas melarang bahwa jika memaksakan untuk melakukan aktifitas yang justru mengancam jiwanya maka perbuatannya tidak bermaslahat. Karena kemaslahatan jiwa harus diutamakan dan diprioritaskan. Hal ini sejalan dengan anjuran bahwa warus berdia dirumah agar baik diri masingmasing, keluarga serta masyarakat lainnya tidak tertulari virus corona.

\section{Kesimpulan}

Maqasid al-syariah merupakan suatu konsep yang mengutamakan kemaslahat kehidupan manusia baik di dunia maupun di akhirat. Fenomena virus Corona yang mewwabah saat ini memang diakui mengganggu stabilitas termasuk dalam hal ibadah. Namun ibadah yang ditinggalkan seperti salat jumat bukanlah mengganggu dan mengancam eksistensi agama karena ada pilihan lain yang menjadi alternative ibadah yaitu salat duhur. Hal ini berdasakan bahwa adanya suatu uzur sehingga gugurnya suatu kewajiban yang diakibatkannya. Virus Corona mengancam eksistensi jiwa manusia, sehingga manusia harus menghindarkan dirinya pada virus tersebut. Salah satu ajaran agama sekaligus menjadi anjuran pemerintah adalah berdiam diri di rumah masing-masing dan menghindari kerumunan agar penyebarannya tidak meluas. Ajaran agama mewajibkan melakukan aktifitas ibadah dalam menjalankan agama akan tetapi jika mengancam eksistensi jiwa maka anjuran tersebut pasti ada alternative lainnya. 


\section{Daitar Pustaka}

Baroroh, Nurdhin. "Metamorfosis Illat Hukum Dalam Sad Adz-Dzari' ah Dan Fath Adz-Dzari'ah." Al-Mazahib 5, no. 2 (2017): 289-304.

Farida, Farida, and Veni Soraya Dewi. "Analisis Pengaruh Penerapan Kinerja Maqasid Terhadap Manajemen Risiko Pada Perbankan Syariah." Cakrawala: Jurnal Studi Islam 12, no. 2 (2017): 171-86. https://doi.org/10.31603/cakrawala.v12i2.1858.

Hidayatullah, Kholid. "Mazhab Ulama Dalam Memahami Maqashid Syari>ah." Ulul Albab: Jurnal Studi Dan Penelitian Hukum Islam 1, no. 1 (2017): 1. https://doi.org/10.30659/jua.v1i1.1971.

Hukum, Transformasi, Islam Di, Indonesia Darussalam, Abstrak Tulisan, Setelah Indonesia, Hukum Islam, and Islam Indonesia. "Guru Besar Dalam Bidang Ilmu Pemikiran Hukum Islam Pada Fakultas Syariah Dan Hukum UIN Alauddin Makassar. Jurnal Al-Qadau Volume 2 Nomor 1/2015 |*” 2 (2015): 1-14.

Indra. "Maqashid Syariah Menurut Muhammad Thahir Bin Asyur," 2016, 112. https://drive.wps.com/d/ANxjamCko-gboMioxIydFA\%0A[Berkas]Maqashid Syariah menurut Muhammad Thahir bin Asyur.pdf.

Jamal, Ridwan. "Maqashid Al-Syari'Ah Dan Relevansinya Dalam Konteks Kekinian." Jurnal Ilmiah Al-Syir'ah 8, no. 1 (2016): 1-12. https://doi.org/10.30984/as.v8i1.34.

Lexy J. Moleong. Metodologi Penelitian Kualitatif. Edited by XXXI. Bandung: PT. Remaja Rosdakarya, 2013.

Musolli, Musolli. "Maqasid Syariah: Kajian Teoritis Dan Aplikatif Pada Isu-Isu Kontemporer.” AT-TURAS: Jurnal Studi Keislaman 5, no. 1 (2018): 60-81. https://doi.org/10.33650/at-turas.v5i1.324.

Sugiyono. Metode Penelitian Kombinasi. Cet: II. Bandung: Alfabeta, 2012.

Sukardi. Metodologi Penelitian Pendidikan Kompetensi Dan Praktiknya. Cet: II. Jakarta: PT. Bumi Aksara, 2004. 
Zatadini, Nabila, and Syamsuri Syamsuri. "Konsep Maqashid Syariah Menurut Al-Syatibi Dan Kontribusinya Dalam Kebijakan Fiskal." AL-FALAH : Journal of Islamic Economics 3, no. 2 (2018): 1. https://doi.org/10.29240/alfalah.v3i2.587.

Muhammad Musa al-Tiwana, Ijtihad wa Mada Hajatina Ilaih fi Hadza al-'Asr (T,t, Dar Kutub al-Hadisah, t.th).

Abd Al-Rahman Ibrahim al-Kailani, Qawaid al-Maqasid inda al-Imam al-syatibi: 'Ardan wa Dirasatan wa Tahlilan (Damishq: Dar alFikr, 2000), 46

Al-Syatibi, Al-Muwafaqat fi Ushul al-Syariah ( Kairi: Mustafa Muahammad, $t, t h) h$.

Al-Ghazali, al-Mustasfa min 'Ilm al-Ushul, Jilid I (Kairo: al- Amiriyyah, 1412), h. 250

Soerjono Soekanto, Pokok-Pokok Sosiologi Hukum ( Jakarta: Rajawali Pres, 1980).

https://tafsirweb.com/10718-quran-surat-al-hadid-ayat-22.html

https://news.detik.com/berita/d-4956298/daftar-negara-yang-lockdownkarena-corona $/ 5$

Aplikasi HadisSoft versi 4.0.0 